\title{
Shunt Device
}

National Cancer Institute

\section{Source}

National Cancer Institute. Shunt Device. NCI Thesaurus. Code C50174.

An implantable device designed to drain fluid from a body cavity. 